\title{
Characterization of the hospitalization of children and adolescents with cancer
}

\author{
Raquel Pan ${ }^{1}$ \\ Amanda Rossi Marques ${ }^{2}$ \\ Moacyr Lobo da Costa Júnior ${ }^{3}$ \\ Lucila Castanheira Nascimento ${ }^{4}$
}

\begin{abstract}
This study characterizes hospitalizations of children and adolescents with cancer, from 1998 to 2008, to describe the clientele in follow-up in the Regional Health Area of Ribeirão Preto, SP, Brazil. Morbidity was surveyed in Ribeirão Preto, SP, Brazil, using hospitalization data from the Unified Health System. The studied variables included: origin, residence, year when care was provided, deaths, age and gender of patients diagnosed with child and adolescent cancer according to the International Classification of Disease 10th edition, Chapter II. The results indicated 7,234 hospitalizations of individuals younger than 18 years old diagnosed with neoplasm, 95\% of which were from Ribeirão Preto, SP, Brazil, and the remainder from cities located in all five of the Brazilian regions. Identifying the characteristics of patients contributes to the identification of information to broaden the sensitization of health professionals concerning the need for secondary preventive actions, such as early diagnosis.
\end{abstract}

Descriptors: Neoplasms; Child; Adolescent; Delivery of Health Care; Morbidity.

\footnotetext{
${ }^{1}$ RN, Doctoral Student in Nursing, Programa Interunidades de Pós-graduação em Enfermagem, Escola de Enfermagem da Universidade de São Paulo and Escola de Enfermagem de Ribeirão Preto, Universidade de São Paulo, WHO Collaborating Centre for Nursing Research Development, SP, Brazil. E-mail: raquelpan@bol.com.br.

2 Undergraduate student in Nursing, Escola de Enfermagem de Ribeirão Preto, Universidade de São Paulo, WHO Collaborating Centre for Nursing Research Development, SP, Brazil. Scholarship holder of the Scientific Initiation Program (PIC) Santander. E-mail: a_mandamarques@hotmail.com.

${ }_{3}^{3}$ Statistician, Ph.D. in Public Health, Associate Professor, Escola de Enfermagem de Ribeirão Preto, Universidade de São Paulo, WHO Collaborating Centre for Nursing Research Development, SP, Brazil. E-mail: mlobojr@eerp.usp.br.

${ }^{4}$ RN, Ph.D. in Nursing, Professor, Escola de Enfermagem de Ribeirão Preto, Universidade de São Paulo, WHO Collaborating Centre for Nursing Research Development, SP, Brazil. E-mail: lucila@eerp.usp.br.
}

Corresponding Author:

Lucila Castanheira Nascimento

Universidade de São Paulo. Escola de Enfermagem de Ribeirão Preto

Departamento Materno-Infantil e Saúde Pública

Av. dos Bandeirantes, 3900

Bairro: Monte Alegre

CEP: 14040-902, Ribeirão Preto, SP, Brasil

E-mail: lucila@eerp.usp.br 


\title{
Caracterização das internações hospitalares de crianças e adolescentes com neoplasias
}

Este estudo objetivou caracterizar as internações hospitalares de crianças e adolescentes com neoplasias, ocorridas de 1998 a 2008, para conhecer a clientela em seguimento na Regional de Saúde de Ribeirão Preto, SP, Brasil. Realizou-se levantamento da morbidade nesse município, utilizando-se, como fonte de informação, as internações hospitalares pelo Sistema Único de Saúde. As variáveis estudadas foram: procedência, residência, ano do atendimento, óbitos, idade e sexo dos pacientes com diagnóstico de neoplasia infantojuvenil, segundo o Capítulo II da Classificação Internacional de Doenças, $10^{a}$ edição. Evidenciaram-se 7.234 internações de menores de 18 anos com diagnóstico de neoplasias; dessas, 95\% eram de Ribeirão Preto, SP, Brasil, e o restante procedentes de municípios das cinco regiões do país. Conhecer as características da clientela atendida contribui para a identificação de informações que podem ampliar o processo de sensibilização dos profissionais de saúde, para a necessidade de ações de prevenção secundária, como o diagnóstico precoce.

Descritores: Neoplasias; Criança; Adolescente; Assistência à Saúde; Morbidade.

\section{Caracterización de las internaciones hospitalarias de niños y adolescentes con neoplasias}

\begin{abstract}
Este estudio tuvo por objetivo caracterizar las internaciones hospitalarias de niños y adolescentes con neoplasias, de 1998 a 2008, para conocer la clientela en seguimiento en la Regional de Salud de Ribeirao Preto, Sao Paulo, Brasil. Se realizó un levantamiento de la morbilidad en Ribeirao Preto, utilizando, como fuente de información, las internaciones hospitalarias por el Sistema Único de Salud. Las variables estudiadas fueron: procedencia, residencia, año de la atención, muertes, edad y sexo de los pacientes con diagnóstico de neoplasia infanto-juvenil, según el Capítulo II de la Clasificación Internacional de Enfermedades $10^{a}$ edición. Se constataron 7.234 internaciones de menores de 18 años con diagnóstico de neoplasias, de estas, 95\% ocurrieron en Ribeirao Preto y las otras en municipios de procedencia pertenecientes a las cinco regiones del país. Conocer las características de la clientela atendida contribuye para identificar informaciones que pueden ampliar el proceso de sensibilización de los profesionales de salud para la necesidad de realizar acciones de prevención secundaria, como el diagnóstico precoz.
\end{abstract}

Descriptores: Neoplasias; Niño; Adolescente; Prestación de Atención de Salud; Morbilidad.

\section{Introduction}

Cancer represents a public health problem both for developed and developing countries ${ }^{(1)}$. Compared to adult cancer, child cancer can be viewed as rare because it corresponds to $1 \%$ to $3 \%$ of all new cases of malignant neoplasm in the world(2), though with considerable expressiveness in the context of diseases in childhood and adolescence. The Brazilian National Cancer Institute (INCA) estimated 9,386 new cases for 2010 while the average percentage of child cancer observed in the Population-
Based Cancer Registries (RCBP) is close to $2.5 \%{ }^{(3)}$.

Leukemia is the type of cancer that predominates in childhood. Among all types of leukemia, Acute Lymphoid Leukemia (ALL) is the most frequent among children from zero to 14 years old; bone tumors affect adolescents and the most frequent ones are Ewing's sarcoma and osteosarcoma(3).

As opposed to cancer in adulthood, pediatric neoplasm does not present a clear association with risk 
factors or particular behaviors. It is known, however, that cancer affecting children and youth present lower periods of latency. They generally grow quickly and are more invasive, though they respond better to treatment and in most cases are considered to have a good prognosis. Currently, $75 \%$ of children affected by cancer survive five years of more after the diagnosis( ${ }^{(4)}$.

The Brazilian policy to control cancer evidences the importance of obtaining an early diagnosis, emphasizing human resources education so professionals become attentive to this strategy, which can greatly influence the prognosis of children and adolescents with cancer, diminishing morbidity and mortality caused by this disease ${ }^{(4)}$.

There are in the city of Ribeirão Preto, SP, Brazil hospitals that deliver care to children and adolescents with a diagnosis of neoplasm, though we highlight one university hospital of reference in tertiary care provided to this disease that is a center that educates specialized human resources in the field. Because of this hospital's high technology resources, it attracts patients from surrounding cities and different regions of Brazil, not always within its scope area. This characteristic can hinder the follow-up of children and adolescents of families living outside the city(5) of Ribeirão Preto and also limit the supply of other types of important care procedures, such as home visits to monitor the child and family financial aid for the family to commute to the treatment center(6), cooperation with the family support network, and proximity to the child's school(7), among others.

Based on the preceding discussion and to explore the problem within the collective health scope, this study characterized hospitalizations of children and adolescents with cancer, from 1998 to 2008, in order to identify and classify the contingent of patients who have their follow-up performed in the Regional Health Area of Ribeirão Preto, SP, Brazil. Identifying the profile of this population can help gather information to broaden the process of sensitization of health professionals to an early diagnosis as one of the main strategies in secondary prevention.

\section{Method}

This is a descriptive and quantitative study. Because it exclusively used secondary data and also because Department of Information of the Unified Health System (DATASUS) is a database in the public domain in which the identification of involved individuals is not possible, there was no need to submit the project to the Human Research Ethics Committee.

To achieve the proposed objective, a survey of data concerning mortality was conducted in the city of Ribeirão Preto using hospitalization data within the Unified Health System (SUS) available from the Ministry of Health at www.datasus.gov.br; the information concerns health/epidemiological matters and morbidity/ hospital morbidity ${ }^{(8-9)}$. The studied variables included: origin, residence, year when care was provided, deaths, age and gender of patients with child-adolescent cancer according to the Chapter II of $10^{\text {th }}$ edition of the International Disease Classification (ICD - 10)(10). Recommendations provided in the literature were used to obtain data(11). Hence, to characterize hospitalizations and identify patients with child-adolescent cancer who come from other cities outside of the Regional Health area in Ribeirão Preto, more than 20 temporary files were generated during the conduct of this study to make sure no data were lost or duplicated. First, we obtained a database with all the hospitalizations that occurred in the Regional Health area of Ribeirão Preto, SP, Brazil from 1998 to 2008, regardless of diagnosis or age. Based on this first database, a second one was generated with children younger than 18 years of age, also regardless of diagnosis. Lastly, a third database was obtained with those younger than 18 years old with a primary or secondary diagnosis of cancer.

Special care was taken during data collection in relation to the established age range so no hospitalization was lost because the DATASUS provides data concerning age, divided into individuals younger than one year old (days and months) and older than one year old (1 to 4; 5 to $9 ; 10$ to 14 ; and 15 to 19 ). Hence, we first obtained data concerning children with days and months of life, then, results represented the population of individuals older than one year of age up to those younger than 18 years old. The definition of child and adolescent upon which the selection of age was based in this study was the Statute of Children and Adolescent according to Law No. 8,069 from July $13^{\text {th }} 1990$, Article 2, which provides that a child is anyone younger than 12 years old and an adolescent is anyone older than 12 years old and younger than 18 years old(12).

The diagnoses were selected according to the Chapter II of $10^{\text {th }}$ edition of the International Disease Classification $(I C D-10)^{(10)}$, from the primary and secondary diagnostic fields. Chapter II from ICD 10 is divided into four groups: C00-C97 - Malignant neoplasms, D00-D09 - In situ neoplasms, D10-D36 
- Benign neoplasms, and D37-D48 - Neoplasms of uncertain or unknown behavior. Among these four groups, only the malignant neoplasm is subdivided into another four: C00-C75 - Malignant neoplasms, stated or presumed to be primary, of specified sites, except of Iymphoid, hematopoietic and related tissue; C76-C80 - Malignant neoplasms of ill-defined, secondary and unspecified sites; C81-C96 - Malignant neoplasms, state or presumed to be primary, of lymphoid, hematopoietic and related tissue; $\mathrm{C97}$ - Malignant neoplasm or independent (primary) multiple sites.

To describe the variable 'origin', we established criteria for the distance of these cities in relation to the facility located in Ribeirão Preto, SP, Brazil, classifying them into: near, intermediate, and far. Using Ribeirão Preto as the reference, we stipulate being near as those cities at a distance equal to or less than 100 $\mathrm{km}$; intermediate as those with distances greater than $100 \mathrm{~km}$ and less than $500 \mathrm{~km}$; and far as those with distances greater than $500 \mathrm{~km}$.

The database was organized within the program EpiInfo 6 for later descriptive and exploratory analyses using the Chi-square test to verify association between the variables 'gender' and 'death' and the average test for 'gender', 'duration of hospitalization' and 'age'.

\section{Results}

The Regional Health area of Ribeirão Preto, SP, is composed of 26 cities presented in Table 1 . The cities with the most expressive population are Ribeirão Preto and Sertãozinho with 563,107 and 110,998 respectively. Currently, Ribeirão Preto represents 44\% and Sertãozinho $8.6 \%$ of the population in the Regional Health area.

A total of $1,016,183$ hospitalizations occurred between 1998 and 2008 in the Regional Health area of
Ribeirão Preto, regardless of diagnosis or age; 191,132 hospitalizations were individuals younger than 18 years old and 7,234 of these had neoplasm as the primary or secondary diagnosis, which corresponds to $0.7 \%$ of the total hospitalizations. There was no significant variation in the number of hospitalizations over the years within this period. The highest number of hospitalizations was recorded in 2005 with a total of 712 and 2001 was the year with the lowest number of hospitalizations (533).

Ribeirão Preto, SP accounted for $62.8 \%$ of the total hospitalizations in the period; $62.4 \%$ of the hospitalizations were individuals younger than 18 years old and $94.6 \%$ of individuals younger than 18 years old had a diagnosis of neoplasm. Sertãozinho accounted for $5.3 \%$ of total hospitalizations; $5.7 \%$ of hospitalizations of individuals younger than 18 years old and $1.4 \%$ of those with a diagnosis of neoplasm (Table 1).

Of the 26 cities in the Regional Health area of Ribeirão Preto, SP, Brazil, 11 (Barrinha, Brodowski, Cajuru, Cássia dos Coqueiros, Dumont, Guatapará, Luís Antônio, Pradópolis, Santa Cruz da Esperança, Santo Antônio da Alegria, Serra Azul) do not have hospitals though they have Mixed Health Units, Primary Health Care Units and Family Health Programs(13). Of these, seven cities (Brodowski, Cássia dos Coqueiros, Dumont, Guatapará, Luís Antônio, Pradópolis, Santa Cruz da Esperança) did not present any hospitalizations in the studied period and in the remaining four (Barrinha, Cajuru, Santo Antônio da Alegria e Serra Azul), hospitalizations of the studied population were observed, suggesting that such hospitalizations occurred in non-hospital facilities such as Mixed Health Units (Table 1). Hospitalizations outside of Ribeirão Preto but within the Regional Health area refer to the population resident in the city only with the exception of two cases.

Table 1 - Absolute numbers and percentage of the resident population, SUS total hospitalizations, hospitalization of individuals younger than 18 years old and hospitalizations of individuals younger than 18 years old diagnosed with a neoplasm in the Regional Health Area of Ribeirão Preto, SP, Brazil, 1998 to 2008

\begin{tabular}{|c|c|c|c|c|c|c|c|c|}
\hline City & Population & Percentage & $\begin{array}{c}\text { Total } \\
\text { Hospitalization }\end{array}$ & Percentage & $\begin{array}{l}\text { Hospitalizations } \\
<18 \text { years old }\end{array}$ & Percentage & $\begin{array}{c}\text { Hospitalizations } \\
<18 \text { years old, } \\
\text { neoplasm }\end{array}$ & Percentage \\
\hline Altinópolis & 15,550 & 1.2 & 11,091 & 1.1 & 1,617 & 0.8 & 3 & 0.0 \\
\hline Barrinha & 27,167 & 2.1 & 1,747 & 0.2 & 598 & 0.3 & 1 & 0.0 \\
\hline Batatais & 56,485 & 4.4 & 40,976 & 4.0 & 8,319 & 4.4 & 38 & 0.5 \\
\hline Brodowski & 20,487 & 1.6 & - & - & - & - & - & - \\
\hline Cajuru & 24,315 & 1.9 & 22,274 & 2.2 & 5,455 & 2.9 & 37 & 0.5 \\
\hline Cássia dos Coqueiros & 2,729 & 0.2 & - & - & - & - & - & - \\
\hline Cravinhos & 30,848 & 2.4 & 8,455 & 0.8 & 833 & 0.4 & 3 & 0.0 \\
\hline
\end{tabular}


Table 1 - (continuation)

\begin{tabular}{|c|c|c|c|c|c|c|c|c|}
\hline City & Population & Percentage & $\begin{array}{c}\text { Total } \\
\text { Hospitalization }\end{array}$ & Percentage & $\begin{array}{l}\text { Hospitalizations } \\
<18 \text { years old }\end{array}$ & Percentage & $\begin{array}{c}\text { Hospitalizations } \\
<18 \text { years old, } \\
\text { neoplasm }\end{array}$ & Percentage \\
\hline Dumont & 8,352 & 0.7 & - & - & - & - & - & - \\
\hline Guariba & 34,510 & 2.7 & 27,080 & 2.7 & 7,093 & 3.7 & 32 & 0.5 \\
\hline Guatapará & 6,375 & 0.5 & - & - & - & - & - & - \\
\hline Jaboticabal & 73,070 & 5.7 & 24,864 & 2.4 & 5,562 & 2.9 & 10 & 0.2 \\
\hline Jardinópolis & 37,473 & 2.9 & 11,396 & 1.1 & 1,222 & 0.6 & 12 & 0.2 \\
\hline Luís Antônio & 11,922 & 0.9 & - & - & - & - & - & - \\
\hline Monte Alto & 45,899 & 3.6 & 30,007 & 3.0 & 7,488 & 3.9 & 20 & 0.3 \\
\hline Pitangueiras & 35,440 & 2.8 & 16,495 & 1.6 & 3,638 & 1.9 & 51 & 0.7 \\
\hline Pontal & 39,270 & 3.1 & 14,844 & 1.5 & 4,092 & 2.1 & 38 & 0.5 \\
\hline Pradópolis & 16,620 & 1.3 & - & - & - & - & - & - \\
\hline Ribeirão Preto & 563,107 & 43.8 & 637,983 & 62.8 & 119,236 & 62.4 & 6,844 & 94.6 \\
\hline Santa Cruz da Esperança & 1,721 & 0.1 & - & - & - & - & - & - \\
\hline Santa Rita do Passa Quatro & 27,559 & 2.1 & 67,189 & 6.6 & 4,768 & 2.5 & 16 & 0.2 \\
\hline Santa Rosa de Viterbo & 24,052 & 1.9 & 10,684 & 1.0 & 1,857 & 1.0 & 7 & 0.1 \\
\hline Santo Antônio da Alegria & 6,341 & 0.5 & 2,536 & 0.3 & 357 & 0.2 & 1 & 0.0 \\
\hline São Simão & 14,329 & 1.1 & 9,474 & 0.9 & 1,434 & 0.8 & 1 & 0.0 \\
\hline Serra Azul & 10,124 & 0.8 & 48 & 0.0 & 2 & 0.0 & - & - \\
\hline Serrana & 39,575 & 3.1 & 24,987 & 2.5 & 6,624 & 3.5 & 19 & 0.3 \\
\hline Sertãozinho & 110,998 & 8.6 & 54,053 & 5.3 & 10,937 & 5.7 & 101 & 1.4 \\
\hline Total & $1,284,318$ & 100.0 & $1,016,183$ & 100.0 & 191,132 & 100.0 & 7,234 & 100.0 \\
\hline
\end{tabular}

Source: www.datasus.gov.br raw data retrieved in April 2009.

There were a total of 7,234 hospitalizations due to neoplasms, among which, children younger than one year of age included 154 boys and 175 girls; 6,905 hospitalizations were children older than one year of age and younger than 18 years old, of which 3,731 were boys and 3,174 were girls (Table 2 ).

Table 2 - Distribution of hospitalizations of children and adolescents with neoplasms according to age and gender in the Regional Health Area of Ribeirão Preto, SP, Brazil, 1998 to 2008

\begin{tabular}{lccc}
\hline \multicolumn{1}{c}{ Age/Gender } & Male & Female & Total \\
\hline Days & 18 & 27 & 45 \\
Months & 136 & 148 & 284 \\
Years & 3,731 & 3,174 & 6,905 \\
Total & 3,885 & 3,349 & 7,234 \\
\hline
\end{tabular}

Source: www.datasus.gov.br raw data retrieved in April 2009.

Duration of hospitalization ranged from zero to 117 days; boys remained an average of 6.4 days and girls an average of 5.7 days. The relationship between gender and duration of hospitalization is statistically significant $(p=0.0006)$. In relation to gender and age, hospitalized girls are older than boys; the average age of boys was 8.45 years old and 9.10 years old for girls; the difference is statistically significant $(p=0.0382)$. Among the children older than one year of age, more hospitalizations were observed in children three, two and four years old, respectively. The average age of children older than one year of age was 8.75 years old.

There were 174 deaths (2.4\%) among children younger than 18 years of age with a diagnosis of neoplasm and two third of which were boys; a statistically significant relation was found between gender and death $(p<0.01)$.

The group with a greater concentration of diagnoses in the chapter II ICD-10(10) is malignant neoplasms with 4,863 cases. Lymphoid leukemia is the most frequent with 1,127 cases followed by malignant brain tumors (668) and myeloid leukemia (366). The group with the second highest number of occurrences is benign neoplasms (tumors), with 1,158 cases, of which hemangioma and lymphangiomas, any site, account for 328 cases.

A total of 7,234 hospitalizations were identified in the 11 studied years of individuals younger than 18 years old with a diagnosis of neoplasm. In $93.5 \%$ of this total, neoplasm was the primary diagnosis and in $6.5 \%$ it was the secondary diagnosis (Table 3 ). 
Table 3 - Distribution of hospitalizations of children and adolescents with neoplasm as the primary and secondary diagnosis in the Regional Health Area of Ribeirão Preto, SP, Brazil, 1998 to 2008

\begin{tabular}{lcc}
\hline \multicolumn{1}{c}{ Diagnoses } & Number & Percentage \\
\hline Neoplasm as the primary diagnosis & 6,761 & 93.5 \\
Secondary diagnosis: & 1,149 & \\
Neoplasm & & \\
Diseases other than neoplasm & 448 & \\
No secondary diagnosis & 5,164 & \\
Neoplasm as the secondary diagnosis & 473 & 6.5 \\
Total & 7,234 & 100.0 \\
\hline
\end{tabular}

Source: www.datasus.gov.br raw data retrieved in April 2009.

The population studied in the period selected for this study originated from 290 cities, including Ribeirão Preto itself. The cities are located in all the five regions in the country: midwest, north, northeast, south and southeast. Data analysis revealed that 47 cities were near, including Ribeirão Preto, 167 were intermediate and 76 were far cities. All those considered to be near are located in the state of São Paulo; most of the intermediate are in the state of São Paulo followed by cities in the interior of Minas Gerais, one in Paraná and two in Mato Grosso do Sul and another in Goiás. The far cities belong to the remaining regions in the country(14).

\section{Discussion}

This study was motivated by the relevance of child-adolescent cancer among the chronic conditions affecting this population and also given the need to know the profile of the pediatric clientele with a diagnosis of neoplasm cared for in the Regional Health Area of Ribeirão Preto, SP, Brazil. In the scope of this study (11 years), the number of primary or secondary diagnoses of neoplasms $(7,234)$ does not represent an expressive number in relation to the total number of hospitalizations $(1,016,183)$. However, we cannot fail to mention the impact of such diagnoses on the affected children, adolescents and their families and also society in general.

This study corroborates literature(15) showing that the male gender remained hospitalized longer than the female gender. The relation between 'gender' and 'duration of hospitalization' was statistically significant, though clinically this difference only represents an additional day of hospitalization.

Various pediatric tumors affect the population from zero to 18 years old with a greater or lower incidence according to the specificities of each age group and geographic region ${ }^{(15)}$. Those younger than 15 years of age are more frequently diagnosed with leukemia, lymphoma, tumors in the Central Nervous System (CNS), and sympathetic system and Wilms' tumor(15-16). As identified in this study, among all the pediatric neoplasms, leukemia is the most frequently diagnosed, laccounting for $25 \%$ to $35 \%$ of all malignant pediatric neoplasms in most populations; the most prevalent ones are acute. Chronic myeloid leukemia is not common among children. The incidence of leukemia is greater among boys than among girls in virtually all the cities studied in a search(15) recently conducted, with the exception of Recife, PE, Brazil. In developed countries, tumors in the CNS represent the second most common diagnosis in childhood followed by lymphomas, corroborating this study's results. This order is inverted in developing countries where lymphomas are ranked second and tumors in the CNS are ranked third(17).

Studies also indicated that children from one to four years of age remained hospitalized longer, a result similar to that found in another study, which shows that younger pediatric age groups are more likely to develop cancer, with the exception of lymphomas that predominate among adolescents aged 15 to 18 years old $^{(17)}$.

The results of many Brazilian specialized services are comparable to those in developed countries, however there are regional differences in relation to the supply of health services so that survival rates in Brazil are below those expected given the current technical development and knowledge(5). The city of Ribeirão Preto, SP is a center in the field of cancer and hematological diseases care. It has a university tertiary hospital with highlevel technology and specialized human resources and, consequently, attracts patients from surrounding cities and all regions in the country.

The macro-strategy of the regionalization of SUS should consider a set of proposals regulated in the SUS Operational Standards of Health Care 01/01 to ensure users have equal access to actions and services at the levels of complexity required to solve their health problems. However, the system organization networks should refer to delimited territories and defined populations ${ }^{(18)}$. Hence, this study suggests that the organization of the Brazilian Health System has experienced failures in its structure, e.g. the referral of patients, from near and intermediate cities that have their own referral centers to care for this type of disease in their regional health areas, to the Regional Health Area of Ribeirão Preto, SP. A thorough investigation 
concerning the reason that motivated these children and adolescents to travel in order to receive treatment out of their areas of coverage would be desirable and could favor understanding concerning the situation in order to devise strategies to cope with it.

The patients who do not live in the center's coverage area come from the five regions in the country, which portrays the fragility, insufficiency or nonexistence of services to meet the needs of the pediatric population in the field of oncology. It becomes evident as we observe patients coming from other referral centers, especially from near cities, to be cared for in Ribeirão Preto-SP.

Children and adolescents coming from near cities, according to the classification adopted in this study, can have their access to this tertiary health service facilitated whereas those coming from intermediate and far cities face difficulty accessing care and not return to the service with the ideal frequency due to the distance ${ }^{(6)}$ and financial difficulties(19), which may interfere on the patient's follow-up and in the bonds established between the health team and the patient and his/her family.

Based on this study's results obtained through information available in DATASUS, we could delineate the characteristics of the child-adolescent population affected by cancer and cared for in the Regional Health Area of Ribeirão Preto, SP. For a more detailed characterization of this population, the collection of information based on other sources such as the medical files of these children and adolescents or conducting interviews with the families coming from regions outside of the Regional Health Area of Ribeirão Preto, SP could help identify the difficulties accessing health services, especially concerning the implementation of actions to strengthen early diagnosis. These are possibilities for future research.

Even though the objective of this study was not the generalization of results, a limitation is the fact it was developed with a focus in a single Regional Health Area, thus its results cannot be applied to the entire Brazilian context. Studies of this nature can characterize the child-adolescent population with a diagnosis of cancer cared for in other regional health areas and explore the occurrence of care provided outside of their scope areas, as well as the reasons individuals seek care in other locations.

\section{Conclusions}

The characterization of hospitalization of children and adolescents with neoplasm supports the identification of the characteristics of the population cared for in the Regional Health Area in Ribeirão Preto, SP, Brazil. The systematization of this information contributes to sensitizing health professionals concerning the need for secondary prevention actions, such as early diagnosis, since cancer is an important cause of death among children and adolescents.

The identification of the origin of patients directly influences the established therapeutic practice and is evidence for potential limitations the health team could face when performing the follow-up of children and adolescents with neoplasms and their families. The supply of services for diagnosing and treating this clientele within the public health network and the conditions of families commuting to the treatment care center are essential for achieving successful treatment.

\section{Acknowledgments}

To the Scientific Initiation Program Scholarships PIC/Santander, by the granting of scientific initiation scholarship, 2009-2010.

\section{References}

1. Bjork M, Wiebe T, Hallstrom I. Striving to survive: families lived experiences when a child is a diagnosed with cancer. J Pediatr Oncol Nurs. 2005;22(5):265-75.

2. Mutti CF, Paula CC, Souto MD. Assistência à Saúde da Criança com Câncer na Produção Científica Brasileira. Rev Bras Cancerol. 2010;56(1):71-83.

3. Ministério da Saúde (BR). Instituto Nacional de Câncer. Estimativa 2010: incidência de câncer no Brasil-2009. [Internet]. [acesso 13 ago 2011]. Disponível em: http:// www.inca.gov.br/estimativa/2010/estimativa20091201.pdf 4. Ministério da Saúde (BR). Instituto Nacional de Câncer. Diagnóstico precoce do câncer na criança e no adolescente-2009. [Internet]. [acesso 10 ago 2011] Disponível em: http://www.inca.gov.br/inca/Arquivos/ publicacoes/livro_ronald_internet.pdf

5. Klassmann J, Kochia KRA, Furukawa TS, Higarashi IH, Marcon SS. Experiência de mães de crianças com leucemia: sentimentos acerca do cuidado domiciliar. Rev Esc Enferm USP. 2008;42(2):321-30.

6. Miedema B, Easley J, Fortin P, Hamilton R, Mathews $M$. The economic impact on families when a child is diagnosed with cancer. Curr Oncol. 2008;15(4):8-13.

7. Nóbrega RD, Collet N, Gomes IP, Holanda ER, Araújo YB. Criança em Idade Escolar Hospitalizada: Significado da Condição Crônica. Texto Contexto Enferm. jul-set 2010;19(3):425-33. 
8. Ministério da Saúde (BR). Departamento de Informática do SUS, DATASUS. Base de dados das Informações de Saúde: Morbidade hospitalar do SUS por local de internação - Brasil-2009. [Internet]. [acesso 7 abr 2009]. Disponível em: http://tabnet.datasus.gov. br/cgi/deftohtm.exe?sih/cnv/mibr.def./

9. Ministério da Saúde (BR). Departamento de Informática do SUS, DATASUS. Base de dados das Informações de Saúde: Morbidade hospitalar do SUS - por local de internação - Brasil-2009. [Internet]. [acesso 13 abr 2009]. Disponível em: http://tabnet. datasus.gov.br/cgi/deftohtm.exe?sih/cnv/nibr.def

10. Organização Mundial da Saúde. OMS. CID-10: Classificação Estatística Internacional de Doenças e Problemas Relacionados à Saúde. 10a ed. São Paulo (SP): Universidade de São Paulo; 1997. v. 1, 2.

11. Costa ML Júnior. Estatística de saúde on-line: teoria e prática [tese livre-docência]. Ribeirão Preto: Universidade de São Paulo, Escola de Enfermagem de Ribeirão Preto; 2006.

12. Lei n.8.069, de 13 de julho de 1990 (BR). Dispõe sobre o Estatuto da Criança e do Adolescente e dá outras providências. [Internet]. 1990. [acesso 11 nov 2010]. Disponível em: https://www.planalto.gov.br/ccivil_03/ Leis/L8069.htm

13. Ministério da Saúde (BR). Secretaria de Atenção à Saúde. DATASUS. CENESNet: Cadastro Nacional de Estabelecimentos de Saúde-2009. [Internet]. [acesso 11 nov 2010] Disponível em: http://cnes.datasus.gov. $\mathrm{br} /$ Index. asp? Configuracao $=1280 \&$ bro $=$ Microsoft $\% 20$ Internet\%20Explorer

14. Editora Abril (BR). Guia Quatro Rodas. Guia Rodoviário-2010. [Internet]. [acesso 26 ago 2010] Disponível em: http://mapas.viajeaqui.abril.com.br/ guiarodoviario/guia_Rodoviario_viajeaqui.aspx

15. Reis RS, Santos MO, Thuler LCS. Incidência de tumores pediátricos no Brasil. Rev Bras Cancerol. 2007;53(1):5-15.

16. Ministério da Saúde (BR). Instituto Nacional de Câncer. Sociedade Brasileira de Oncologia Pediátrica, SOBOPE. Câncer da criança e adolescente no Brasil: dados dos registros de base populacional e de mortalidade. Rio de Janeiro: INCA; 2008.

17. Ministério da Saúde (BR). Instituto Nacional do Câncer. Incidência do câncer infantil-2008. [Internet]. [acesso 09 set 2010] Disponível em: http://www.inca. gov.br/releases/press_release_view.asp?ID $=1974$
18. Ministério da Saúde. Secretaria de Assistência à Saúde. Regionalização da assistência à saúde: aprofundando a descentralização com eqüidade no acesso: Norma Operacional da Assistência à Saúde: NOAS-SUS 01/01 e Portaria MS/GM n.0 95, de 26 de janeiro de 2001 e regulamentação complementar [Internet]. Brasília, DF: MS/SAS; 2001 [acesso 27 ago 2011]. Disponível em: http://dtr2001.saude.gov.br/ editora/produtos/livros/pdf/02_0017_M.pdf.

19. Eiser C, Upton P. Costs of caring for a child with cancer: a questionnaire survey. Child Care Health Dev. 2006 Aug;33(4):455-9.
Received: Nov. $18^{\text {th }} 2010$ Accepted: Sept. 20 2011 